Pendidikan Ahlak Dalam Pandangan KH. Abdul Muchith Muzadi

\title{
PENDIDIKAN AHLAK DALAM PANDANGAN KH. ABDUL MUCHITH MUZADI
}

\author{
AHMAD MUTOHAR \\ Fakultas Dakwah IAIN Jember \\ abmadmutohar2013@gmail.com \\ ZAINAL ANSHARI \\ Fakultas Tarbiyah dan Ilmu Keguaruan IAIN Jember \\ zainalanshari@gmail.com
}

\begin{abstract}
ABSTRAK:
KH. Abdul Muchith Muzadi (termasuk juga dikenal dengan sebutan Mbah Muchith Muzadi), termasuk seorang kiai yang memiliki wawasan sangat luas, wara' mendalam dan tajam. Pada saat yang bersamaan, KH. Abdul Muchith Muzadi, termasuk sosok kiai yang memiliki etika sangat kuat, paling tidak hal itu terpancar dalam perilakunya sehari-hari. Beliau tetap berperilaku sebagaimana layaknya kiai yang khusu', wara' dan hidup dengan kesederhanaan. Kajian ini, memiliki fokus sebagai berikut; 1) bagaimana latar belang kehidupan, pendidikan dan pengabdian KH. Abdul Muchith Muzadi di dalam NU dan lembaga pendidikan Islam Indonesia? 2) apa saja karya tulis ilmiah yang dihasilkan oleh KH. Abdul Muchith Muzadi? 3) bagaimana konsep pendidikan ahlak dalam pandangan KH. Abdul Muchith Muzadi? Pendekatan penelitian kualitatif, dengan jenis library research (studi pustaka). Tujuan penelitian ini, untuk menjawab tiga hal yang telah dirumuskan di atas. Berikut kesimpulannya; Pertama, latar belang kehidupan, pendidikan dan pengabdian di dalam NU. KH. Abdul Muchith Muzadi dilahirkan di Bangilan Tuban, pada tanggal 19 jumadil awwal 1344 H/ 4 Desember 1925 M. beliau merupakan kader sekaligus aktivis NU yang dari sejak awal berjuang bersama putra KH. Hasyim Asy'ari, yakni KH. Wahid Hasyim. Kedua, beberapa karya tulis ilmiah KH. Abdul Muchith Muzadi. Sebagai berikut; 1) Beberapa Masalah Kewanitaan Dan Kepemimpinan Di Kalangan Wanita, 1974, makalah tidak diterbitkan. 2) Bermazhab. Sosiologis Atau Takut Resiko? Dalam pesantren No 4/Vol III/1998. Jakarta: P3M. 3) Berusaha memahami kehadiran bank-BPR, dalam majalah AULA. Maret 1991, dan sebagainya. Ketiga, Konsep pendidikan ahlak dalam pandangan KH. Abdul
\end{abstract}

118 | FENOMENA, Vol.19 No. 2 Oktober 2020 
Muchith Muzadi. Konsep pola hidup birrul walidain. Menurutnya, Islam menempatkan birrul walidain ini sebagai kewajiban dengan urutan nomor dua sesudah beribadah kepada Allah dan sebaliknya menempatkan uququl walidain sebagai larangan dengan urutan nomor dua sesudah syirik (menyekutukan Allah).

\section{Kata kunci: pendidikan, ahlak dalam Islam}

\section{PENDAHULUAN}

Aktivis NU atau wagna nahdliyyin, tentu akan sangat familiar dengan nama KH. Abdul Muchith Muzadi. Selain namanya mencuat karena gagasan khittah NU tahun 1984 di muktamar NU Situbondo, ia juga dikenal sebagai orang dekat KH. Ahmad Siddiq, Rais Am Syuriyah PBNU masa kepemimpinan KH. Abdurrahman Wahid (Gus Dur). Namun bukan hanya itu saja sisi unik yang melekat pada KH. Abdul Muchith Muzadi, namun yang membuat menarik untuk memperhatikan dan mengkaji beliau adalah;

Pertama, beliau berlatar belakang pendidikan setara D2, namun pemikirannya diteliti oleh ilmuan-ilmuan di Indonesia, baik dari kampuskampus umum maupun kampus-kampus agama. Bahkan dari luar Indonesia, ada pula yang mengkaji tentang pemikiran beliau, khususnya tentang Islam, NU dan Indonesia. Ini fakta sederhana, namun menarik untuk kita ungkap dan kita urai tentang bagaimana sosok yang sebenarnya KH. Abdul Muchith Muzadi tersebut. ${ }^{1}$

Kedua, KH. Abdul Muchith Muzadi, disebut atau dikenal bahkan populer dengan sebutan nama kiai di kalangan warga Nahdlatul Ulama' (NU) bahkan diluar NU-pun, menilai beliau sebagai seorang kiai. Padahal sebagaimana lumrahnya, seorang kiai itu, syarat paling mendasar setidaktidaknya memiliki santri yang menetap dikomplek pesantren yang dibina dan diasuhnya. Padahal kita tahu, beliau "hanya" tinggal di atas sebidang tanah

\footnotetext{
1 Pertengahan tahun 2010 yang lalu, seorang peneliti perempuan dari Jepang (Mitsuwo Nakamura), datang jauh-jauh ke Jember, hanya ingin ketemu KH. Abdul Muchith Muzadi, dan mengikuti kuliah aswaja yang dibina beliau kepada anak-anak muda NU. Kuliah itu diikuti oleh aktivis PMII dari STAIN Jember, aktivis IPNU/IPPNU Jember, aktivis Fatayat NU Jember.
}

FENOMENA, Vol.19 No. 2Oktober 2020 | 119 
wakaf, tepatnya di depan gedung Universitas Jember, yaitu kompleks Masjid Sunan Kalijaga. ${ }^{2}$

Ketiga, KH. Abdul Muchith Muzadi, merupakan prototipe sebagai seorang kiai, ulama, intelektual, politisi, penulis dan semacamnya, melekat sekali kepada beliau. Padahal, banyak kiai menekuni kemampuan oral dalam menyampaikan dakwahnya. Namun tidak demikian bagi kiai yang konon menjadi kamus NU berjalan ini. Beliau selain berdakwah dengan ceramah, yang tidak kalah menariknya, beliau juga berdakwah dengan tulisan. Bahkan dalam catatan penulis, ada sekitar 37 naskah akademik terbitan bulletin Masjid Al-Baitul Amien Jember, karya KH. Abdul Muchith Muzadi. Sebanyak 7 karya tulis ilmiah dalam bentuk buku, ${ }^{3}$ puluhan pemikiran dalam bentuk wawancara, baik publikasi majalah khittah NU Jember, majalah AULA PWNU Jawa Timur, Koran harian Duta Masyarakat dan lain sebagainya.

Keempat, sebagai mantan aktivis partai politik, mantan wakil ketua DPRD Jember, mantan Sekretaris Daerah (Sekda) Kabupaten Jember, pengurus teras PBNU. Namun beliau tampil sangat sederhana di tengah-tengah masyarakatnya. Beliau tetap santun, ramah dan sejuk bila ditemui oleh siapapun. Bahkan jika beliau sedang sakit, dan kita ajak untuk bicara tentang NU, tentang pengembangan SDM pemuda NU, maka kata beliau "saya lupa, kalau saya sedang sakit". Itulah semangat beliau selalu bersemangat jika berbicara NU dan pemberdayaan kader-kader muda NU.

Bahkan seorang mahasiswa PPs Doktoral IAIN Sunan Ampel Surabaya (sekarang UIN Sunan Ampel Surabaya), MN. Harisudin, mengakhiri

\footnotetext{
${ }^{2}$ Lihat dalam Ayu Sutarto, Menjadi NU Menjadi Indonesia. Surabaya: Khalista \& Kopyawisda Jatim, 2008. Bandingkan dengan Abdul Muchith Muzadi, Mengenal Nahdlatul Ulama, Jember: Masjid Sunan Kalijaga, 2004. Karya tersebut dalam perkembangan selanjutnya, berubah judul menjadi, NU dalam Perspektif Sejarah \& Ajaran (Refleksi 65 Tahun Ikut NU), Surabaya: Khalista, 2006.

${ }^{3}$ Misalkan naskah yang dihasilkan KH. Abdul Muchith Muzadi adalah, 1) NU dan Fikih Kontekstual, Yogyakarta: LKPSM NU DIY, 1995. 2) Dengan Fikih Semua Bisa Halal, Surabaya: Jurnal Gerbang, 1999. No 2, Vol 5 (Oktober-Desember). 3) Menata NU dengan Lisan dan Teladan, Surabaya: Jurnal Gerbang, 2002. No 12, Vol V (JuliSeptember). 4) Mengenal Nahdlatul Ulama, Jember: Masjid Sunan Kalijaga, 2004. 5) NU dalam Perspektif Sejarah \& Ajaran (Refleksi 65 Tahun Ikut NU), Surabaya: Khalista, 2006. 6) Fikih Perempuan Praktis, Surabaya: Khalista. 7) Manivestasi Keluarga Sakinah dalam Pendidikan Anak, Jember: Jurnal Al Adalah, 1998. Vol. 1, No 2 (Agustus). Ini adalah beberapa naskah yang peneliti kumpulkan selama beberapa tahun sebelum dilakukan penelitian ini.
}

120 | FENOMENA, Vol.19 No. 2Oktober 2020 
tugas studi doktoralnya dengan mengangkat pemikiran KH. Abdul Muchith Muzadi. ${ }^{4}$ Ada juga seorang guru besar di Fakultas Sastra Universitas Jember, Prof. Ayu sutarto, yang serius mengkaji pemikiran KH. Abdul Muchith Muzadi terkait pandangannya tentang NU dan Indonesia. ${ }^{5} \mathrm{Hal}$ ini tentu menarik sekali, orang yang berpendidikan setara D2, namun pemikirannya dikaji oleh para ilmuan yang menggunakan metodologi sangat ketat dan selektif. Namun demikian KH. Abdul Muchith Muzadi, tetap memposisikan dirinya dengan sangat tawadlu', dan rendah diri.

Bahkan KH. Abdurrahman Wahid, sempat mengabadikan tentang KH. Abdul Muchith Muzadi dalam sebuah tulisannya yang berjudul "Kiai Nyentrik Membela Pemerintab". Ini menunjukkan sekaliber Gus Dur, memberikan perhatian khusus kepada KH. Abdul Muchith Muzadi, tentu karena beliau dinilai memiliki kapasitas, keunikan intelektual, ikhlas dan tentu karena etikanya. $^{6}$

Inilah letak uniknya KH. Abdul Muchith Muzadi, sebagai seorang kiai yang pemikirannya menjadi ikon/ simbol bagi masyarakat nabdliyyin (warga NU) dan tentu juga bagi Islam Indonesia, namun beliau tetap sederhana, wara', dan menjadi teladan dalam ber-etika, bagi anak-anak muda NU, demikian juga bagi aktivis NU serta masyarakat Islam Indonesia pada umumnya.

Beliau banyak "ditulis" oleh ilmuan, baik dari dalam negeri maupun dari luar negeri. Namun yang membuat beliau menarik kita perhatikan, bukan karena besarnya perhatian orang luar dan dalam negeri yang mengkaji pemikiran beliau, tapi sisi yang jarang dimiliki oleh kalangan intelektual pesantren adalah, beliau juga seorang penulis yang kreatif, produktif dan handal.

Misalkan dalam tulisan M. Muslih Albaroni, yang berjudul, "KH. Abdul Muchith Muzadi makin berisi makin merunduk", ia menggambarkan sosok KH. Abdul Muchith Muzadi sebagai berikut;

4 Mohammad Noor Harisudin, Peran Domestik Perempuan Menurut KH. Abd. Muchith Muzadi. Surabaya: IAIN Sunan Ampel, 2012. Disertasi program doktor.

5 Ayu Sutarto, Menjadi NU Menjadi Indonesia. Surabaya: Khalista \& Kopyawisda, 2008.

6 Abdurrahman Wahid, Kiai Nyentrik Membela Pemerintah. Yogyakarta: LKIS, 2010, hlm, 7-12.

FENOMENA, Vol.19 No. 2Oktober 2020 | 121 
Kalau ada kiai disebut sebagai pakar khitthah, maka yang dimaksud adalah KH. Abdul Muchith Muzadi. Salah satu deklarator PKB. Sebab kiai kelahiran Tuban tahun 1925 inilah yang punya konsep khithah, kembalinya Jam'iyah Nahdlatul Ulama' (NU) ke kancah perjuangan keagamaan, meninggalkan dunia politik praktis. Sejak diputuskan khithah bagi Jam'iyah NU pada Muktamarnya tahun 1984 di Ponpes Salafiyah syafi'iyyah Sukorejo, Situbondo, kesibukan Mbah Muchit (sapaan akrabnya) bertambah. Sebab mbah Muchit-lah yang selalu memberikan penjelasan masalah khithah ke masyarakat. Selain itu juga sering menulis tentang khithah di majalah AULA terbitan PWNU Jawa Timur. Kendati kelahiran daerah pesisir yang kebanyakan bertemperamen keras, tetapi tidak ada sifat keras pada diri mbah Muchit, bahkan sebaliknya penuh dengan kesabaran dan tawadlu', bahkan terkesan sangat hormat kepada siapa saja yang bertamu kepadanya. Hal ini karena keilmuannya yang tinggi dan sudah banyak "makan garam" kehidupan. Pada suatu kesempatan mbah Muchit mengatakan bahwa dirinya dipanggil kiai karena dia punya adik seorang kiai, yakni KH. Hasyim Muzadi pengasuh pesantren mahasiswa Al-Hikam Malang, yang juga Ketua Umum PBNU. Itulah sekilas gambaran Kiai Muchit, ibarat padi makin berisi makin merunduk. ${ }^{7}$

Inilah sosok KH. Abdul Muchith Muzadi, "orang besar" yang penuh dengan kesabaran dan tawadlu', bahkan terkesan sangat hormat kepada siapa saja yang bertamu kepadanya. Tema ini menarik untuk kita amati dan kaji secara mendalam, sebab tidak banyak "orang besar" yang bersikap dan berperilaku seperti beliau. KH. Abdul Muchith Muzadi, sebenarnya seorang kiai besar yang secara keilmuan dan politis sangat berpengaruh. Baik di Jember, Jawa Timur bahkan pada tingkat nasional dan internasional. Namun karena sikap tawadlu' dan rendah dirinya, beliau selalu bilang "dirinya dipanggil kiai karena dia punya adik seorang kiai, yakni KH. Hasyim Muzadi pengasuh pesantren mahasiswa Al-Hikam Malang, yang juga Ketua Umum PBNU”. Ini menandakan bahwa beliau betul-betul termasuk prototipe seorang ulama, intelektual, ilmuan, rohaniawan, kiai, politisi yang perlu kita jadikan teladan dan kaca berkiblat dalam kehidupan.

\footnotetext{
${ }^{7}$ http://suara-santri.tripod.com/files/profil/profil4.htm, diunduh pada 13/10/2014.
}

122 | FENOMENA, Vol.19 No. 2Oktober 2020 
Pangkatnya di NU, tergolong sangat istimewa, karena KH. Abdul Muchith Muzadi tercatat sebagai musytasyar (penasehat) PBNU, namun demikian, KH. Abdul Muchith Muzadi, memposisikan dirinya sebagai kuturunan "orang biasa" artinya bukan dari golongan "darah biru" (golongan keluarga kiai), yang biasanya cenderung memiliki tempat khusus di dalam struktur NU.

Karena walaupun beliau anggota mustasyar PBNU, tapi beliau mengaku bukan sebagai anak kiai atau aktivis pergerakan, tetapi suasana revolusi telah memaksanya untuk aktif di dunia pergerakan, sejak dari pergerakan keilmuan hingga kemerdekaan. Setelah belajar di pesantren Tuban ia melanjutkan belajar kepada Hadlratussyaikh KH. Hasyim Asy'ari di pesantren Tebuireng Jombang. Di Tebuireng, ia tidak hanya belajar agama saja, tapi juga belajar berorganisasi. Karena itu, pada tahun 1941, saat usia muda ia telah menjadi anggota NU. Selain itu, disana ia juga bertemu dengan beberapa santri terkenal dari daerah lain, diantaranya Ahmad Shidiq. ${ }^{8}$

Kendati berwatak tawadlu' tetapi sikap tegas dan konsekuen adalah ciri khas pribadinya. Hal ini pernah beliau tunjukkan baru-baru ini (red, tahun 2008), ketika proses pencalonan gubernur Jawa Timur baru dimulai. Dimana Mbah Muchith dan para kiai sepuh se Jawa Timur berkumpul untuk membahas calon gubernur dari PKB. Diantara keputusan rapat para kiai itu ialah memunculkan nama Saifullah Yusuf, Sekjen DPP PKB, namun nama ini ditolak oleh Ketua Dewan Syuro PKB, KH. Abdurrahman Wahid. ${ }^{9}$

Ada beberapa buku yang terbit, dalam rangka untuk menulis tentang perjalanan KH. Abdul Muchith Muzadi, pertama, buku berjudul "Berjuang Sampai Akhir; Kisah Seorang Mbah Muchith (2006). Ada juga buku berjudul "Menjadi NU, Menjadi Indonesia, Pemikiran KH. Abdul Muchith Muradi, ditulis oleh Prof. Dr. Ayu Sutarto.

\footnotetext{
${ }^{8}$ http://suara-santri.tripod.com/files/profil/profil4.htm, diunduh pada 13/10/2014. Dalam beberapa kesempatan diskusi, wawancara, ceramah pengajian, seminar, sarasehan dan forum-forum ilmiah, KH. Abdul Muchith Muzadi selalu menyampaikan kalau beliau putra dari seorang saudagar biasa, bukan golongan kiai, sebagaimana kiaikiai besar NU lainnya.

${ }^{9}$ http://suara-santri.tripod.com/files/profil/profil4.htm, diunduh pada 13/10/2014.
} 
Buku ini berbeda dengan yang sebelumnya. Kalau buku "Berjuang Sampai Akhir; Kisah Seorang Mbah Muchith, isinya banyak mendiskripsikan biografi Mbah Muchith, sejak masa remaja, pendidikan, pengabdian di masyarakat, organisasi, sampai bagaimana membina kehidupan dalam rumah tangga (keluarga). Dan buku karya Ayu Sutarto ini, isinya lebih pada pemikiran-pemikiran Mbah Muchith tentang ke-NU-an. Misalnya, NU dan Politik, NU dan Muhammadiyah, NU dan Pesantren, NU dan konflik internal, NU dan kiai khos, sampai bagaimana menjadi NU dan Menjadi Indonesia. ${ }^{1}$

Uraian di atas menunjukkan bahwa KH. Abdul Muchith Muzadi termasuk seorang kiai yang memiliki wawasan sangat luas. Pada saat yang bersamaan, KH. Abdul Muchith Muzadi, termasuk sosok kiai yang memiliki etika sangat kuat, paling tidak hal itu terpancar dalam perilakunya sehari-hari. Walaupun berjuang bertahun-tahun untuk kemerdekaan Indonesia, mendirikan berbagai lembaga pendidikan untuk meningkatkan kualitas SDM manusia Indonesia, menjadi dosen di perguruan tinggi agama Islam, sampai perjuangannya di dalam organisasi keagamaan Islam terbesar di Indonesia bahkan di dunia (red, NU), namun beliau tetap berperilaku sebagaimana layaknya kiai yang khusu', wara' dan hidup dengan kesederhanaan. ${ }^{1}$

Komitmennya dalam mempertahankan kemrdekaan Republik Indonesia, komitmennya dalam mengembangkan sumberdaya manusia Indonesia melalui jalur pendidikan, tentu tidak diragukan lagi. Beliau pernah tercatat sebagai anggota legislatif (red, Wakil Ketua DPRD) Kabupaten Jember,

$1 \quad$ http://nu1926.blogsßot.com/2010/09/mbah-muchith-berbincang-nu-dannegara.html, diunduh pada senin, 29 September 2014.

${ }^{1}$ Cara pandang demikian bukảnlah satu hal yang aneh bagi seorang kiai NU. Sebab di dalam NU sendiri, kesederhanaan merupakan satu sikap berorganisasi yang harus dipelihara. Karena kesederhanaan merupakan pengejewantahan daripada sikap-sikap moderat, tasamuh, tawasuth, tawazun dan amar ma'ruf nahi mungkar. Lihat dalam Masyhudi Muchtar, dkk, Aswaja An-Nahdliyah, Ajaran Ahlussunnah Wal Jamaah Yang Berlaku Dilingkungan Nahdlatul Ulama', Surabaya: Khalista \& LTN NU Jawa Timur. Lihat juga dalam A. Ma'ruf Asrori, Etika Belajar Bagi Penuntut IImu; Terjemah Taklimul Mutaallim, Surabaya: Al-Miftah, 2012. Sebagai rujukan juga dalam bersikap KH. Abdul Muchith Muzadi lihat dalam KH. Sirajuddin Abbas, I'tiqad Ahlussunnah Wal Jamaah, Jakarta: Pustaka Tarbiyah Baru, 2008. Bandingkan dengan Muhyiddin Abdusshomad, Aqidah Ahlussunnah Wal Jamaah; Terjemah dan Syarh Aqidah Al Awam, Surabaya: Khalista dan LTN NU Jember, 2009.

124 | FENOMENA, Vol.19 No. 2 Oktober 2020 
pembantu dekan II, di IAIN Jember dan sederet aktivitas pengabdian lainnya.

\section{PEMBAHASAN DAN HASIL PENELITIAN}

Sebagaimana diuraikan Zamakhsyari Dhofier, tradisi pendidikan pesantren di Nusantara, mengharuskan santri belajar dari satu pesantren kepesantren lainnya. Hal ini bukan hanya untuk tujuan mencari ilmu pengetahuan, tapi lebih dari itu, dalam rangka tujuan tabarrukan kepada para kiai pesantren yang dikenal wara' khusu' tawadlu' dan ikhlas dalam mengajarkan ilmunya. Sehingga ilmu yang di dapat santri akan semakin maksimal jika dibarengi dengan keikhlasan yang dimiliki kiai. ${ }^{1}$

Dalam konteks Dhofier di atas, KH. Abdul Muchith Muzadi termasuk tokoh pesantren yang pernah melakukan tradisi "ngalap berkah" tersebut. Walaupun pengalaman organisasinya sangat banyak dan kuat, bahkan KH. Abdul Muchith Muzadi pernah menjadi wakil rakyat, sebagai wakil ketua DPRD Jember dari fraksi NU, namun beliau tetap hidup sederhana dan apa adanya. Inilah sikap lima panca pesantren yang masih melekat pada kepribadian dan kehidupan KH. Abdul Muchith Muzadi sampai saat ini. ${ }^{1}$

KH. Abdul Muchith Muzadi dilahirkan di Bangilan Tuban, pada tanggal 19 jumadil awwal 1344 H/ 4 Desember 1925 M. beliau merupakan kader sekaligus aktivis NU yang dari sejak awal berjuang bersama putra KH. Hasyim Asy'ari, yakni KH. Wahid Hasyim. Dan untuk menerapkan pengetahuannya itu, maka setamat dari Tebuireng ia kembali ke kampung halamannya di Tuban dengan mendirikan Madrasah Salafiyah (1946). Walaupun

1 Lihat dalam Zamakhsyari Dhofier, Tradisi Pesantren; Studi Tentang Pandangan Hidup Kiai, Jakarta: LP3ES, 1994. Dhofier melakukan revisi pada buku tersebut dengan memasukkan respon pesantren terhadap perubahan social melalui politik, Zamakhsyari Dhofier, Tradisi Pesantren; Studi Pandangan Hidup Kiai dan Visinya Mengenai Masa Depan Indonesia, Jakarta: LP3ES, 2011. Lihat dalam tulisannya yang lain, Zamakhsyari Dhofier, Tradisi Pesantren; Memadu Modernitas Untuk Kemajuan Bangsa, Yogyakarta: Pesantren Nawesea Press, 2009.

1 Lihat dalam Abdurrahman Wahid, Menggerakkan Tradisi, Esai-Esai Pesantren, Yogyakarta: LKIS, 2010. Bandingkan dengan Abd. Halim Soebahar, Modernisasi Pesantren; Studi Transformasi Kepemimpinan Kiai Dan System Pendidikan Pesantren, Yogyakarta: LKIS, 2013. Lihat juga dalam Ainur Rofik, Pembaruan Pesantren, Respons Terhadap Tuntutan Transformasi Global, Jember: STAIN Jember press, 2012.

FENOMENA, Vol.19No. 2Oktober 2020 | 125 
sebagai guru ia juga tidak bertopang dagu, tapi ikut berjuang melawan penjajah, masuk ke Lasykar.

Keaktifan Abdul Muchith di dunia pergerakan dan pendidikan, ia jalani sepulang dari pondok asuhan KH. Hasyim Asy'ari ini. Saat Jepang datang menjajah Indonesia, bersama teman-temannya dia mendirikan koperasi desa dengan nama Tokoku ( $\mathrm{Ku}$ dalam Bahasa Jepang artinya desa), sekaligus menjadi sekretarisnya selama dua tahun, 1942-1944. Barangkali karena memiliki aliran darah pedagang, menjadikan Abdul Muchith betah beraktivitas di dalamnya.

Abdul Muchith juga langsung bergabung dengan Hizbullah ketika laskar itu mendirikan cabangnya di daerah Bangilan. Sayang dia tidak bisa mengikuti latihan perwira Hizbullah angkatan pertama di Cibarusa, karena tidak diizinkan orang tuanya. Ia bergabung dengan Hizbullah ketika para alumni pendidikan angkatan pertama itu membentuk Hizbullah di daerah masing-masing. Dirinya bergabung ke dalam Hizbullah setelah setahun berada dalam Suisintai. Di Hizbullah, selain dilatih kemiliteran, ia juga diberi bekal pendidikan kerohanian oleh para ulama.

Kiai Muchith, lantas ditunjuk sebagai Komandan Kompi Hizbullah, tatakala tiga Seksi Hizbullah (Bangilan, Senori dan Singgahan) disederhanakan menjadi satu Kompi Bangilan. Sementara markas utama Batalyon masih tetap di Bojonegoro, dengan Komandan Batalyon Kapten H Romli.

Dengan membawahi 60 orang anak buah, Abdul Muchith bermarkas di rumah Basyar, salah seorang pamannya. Setiap hari Abdul Muchith harus menjalani kehidupan dengan disiplin tentara. Setiap pagi berdinas di markas mengawasi anak buah. Usai Dzuhur dia pulang untuk mengajar di madrasah yang didirikannya bersama masyarakat. Ketika hari mula beranjak malam - dengan menenteng pistol di pinggang - dirinya jalan-jalan ke stasiun untuk melihat situasi. Itu sudah menjadi salah satu kebiasaannya. Termasuk ketika mengajar di sekolah.

Ketika suasana kembali normal, pada tahun 1952 mbah Muchit mendirikan Sekolah Menengah Islam (SMI), selanjutnya pada tahun 1954 juga mendirikan Madrasah Muallimin Nahdlatul Ulama. Begitu juga ketika pada tahun 1961 mendapatkan tugas sebagai pegawai di IAIN Sunan Kalijogo Yogyakarta, maka digunakan kesempatan untuk belajar lagi dengan mengikuti kuliyah di Universitas Cokroaminoto. Di kota gudeg itulah rupanya ia menemukan ide-ide pembaharuan. Maka ketika ditugaskan di IAIN

126 | FENOMENA, Vol.19No.2Oktober 2020 
Malang tahun 1963 iapun sempat merintis SMP NU. Begitu juga ketika menjadi PD II di IAIN Sunan Ampel Jember ia juga mendirikan Madrasah Tsanawiyah. Di seluruh sekolahan yang dirintisnya itu ia bertindak sebagai kepala sekolah. Gerak hidup yang dinamis itu rupanya yang membuat ia tidak mendirikan pesantren secara fisik, sebab pesantren yang dibangunnya lebih luas, seluas komunitas NU.

Penugasan ke IAIN Sunan Ampel Jember rupanya sebuah keberuntungan tersendiri buatnya, sebab disana ia bertemu dengan sahabat seperguruannya yang mengasuh pesantren besar disana, yaitu KH. Achmad Shidiq. Dengan demikian ia menemukan partner diskusi yang seimbang dan sekaligus guru yang bisa diteladani. Masa-masa itu yang semakin mematangkan pemikirannya, sehingga banyak lahir pemikiran keislaman yang ditulis.

Ketika sahabatnya itu menjadi Rais Am Syuriyah PBNU yang saat itu dituntut untuk membuat rumusan konseptual mengebnai Aswaja, menuntaskan hubungan Islam dengan negara dan mencari rumusan pembaruan pemikiran Islam, serta strategi pengembangan masyarakat NU, maka KH. Achmad Shidiq semakin membutuhkan pikiran mbah Muchit. Karenanya ia diangkat sebagai sekretaris yang sekaligus penasehat pribadinya. ${ }^{1}$

\section{a. Latar belakang pendidikan}

Dari ibunya pula, Abdul Muchith bisa membaca al-Qur'an. Selain itu, sang ibu juga mengajarkan pelajaran lain yang bersifat dasar. Untuk menambah wawasan keagamaan, ayah sembilan anak ini lantas mengaji kitab-kitab kecil pada Kyai Ridwan, kyai terkemuka di kampung Bangilan, yang juga masih kerabatnya. Anak pertama dari sembilan bersaudara ini juga nyantri di pesantren Tebuireng Jombang untuk beberapa tahun.

Pendidikannya sangat beragam, baik pendidikan informal, non formal hingga pendidikan formal, berikut gambarannya; 1) Belajar membaca al-qur'an kepada ibunya sendiri, 2) Belajar kitab-kitab keagamaan dasar kepada KH. Ridlwan, Bangilan Tuban, 3) Belajar di Madrasah Miftahussalamah Bangilan, 4) Pada usia 10 tahun, belajar di pondok pesantren kulon banon kajen pati, asuhan KH. Nawawi (1935-1937), 5) Belajar di Madrasah Matholiul Falah, kajen, asuhan KH. Mahfudh salam (ayah KH. A. Sahal

1 Achmad Siddiq, Khittah Nahdliyah, Surabaya: Khalista \& LTN NU Jawa Timur, 2005. 
Mahfudh), 6) Memperbaiki bacaan al-qur'an kepada KH. Salam (ayah KH. Mahfudh) kajen, 7) Belajar di pesantren Tebuireng asuhan KH. Hasyim Asy'ari, selama di sana belajar di madrasah salafiyah syafi'iyah sampai tahun 1937-1941, dan melanjutkan studinya hingga $1942 .{ }^{1}$

\section{b. Latar belakang pengabdian di NU}

Pengabdiannya di NU dapat digambarkan sebagai berikut; 1) Sebagai anggota resmi NU pada tahun 1941, 2) Dan aktif kembali di dalam NU sejak tahun 1952, setelah NU memisahkan diri dari masyumi, 3) Ketua lajnah pemilihan umum NU kabupaten tuban pada pemilu 1955, 4) Wakil NU dalam berbagai jabatan seperti DPRD, panitia pemilihan daerah dsb sejak 1950-1961, 5) Mewakili ansor sebagai ketua panti pemuda dan ketua IPINDO / ikatan pandu Indonesia sebelum dilebur menjadi pramuka di tuban tahun 1957-1961, 6) Sekretaris GP ANSOR Kota Yogyakarta tahun 19611962, 7) Sekretaris GP ANSOR Cabang Malang, 8) Sekretaris Cabang NU Jember tahun 1976-1980, 9) Wakil Ketua Cabang NU Jember 1976-1980, 10) Pengurus LP Ma'arif NU Wilayah Jawa Timur/ Majelis Pembina Madrasah Aliyah 1980-1985, 11) Wakil Rois Syuriyah NU Wilayah Jawa Timur 1985-1990, 12) Rois Syuriyah PBNU 1989-2004 periode Cipasung dan Lirboyo, 13) Mustasyar PBNU 2004-2009 periode muktamar ke 31 Boyolali.

c. Karya tulis ilmiah yang dihasilkan KH. Abdul Muchith Muzadi

Adapun beberapa karya tulis ilmiah yang telah beliau hasilkan adalah sebagai berikut

1) Beberapa Masalah Kewanitaan Dan Kepemimpinan Di Kalangan Wanita, 1974, makalah tidak diterbitkan.

2) Bermazhab. Sosiologis Atau Takut Resiko? Dalam pesantren No 4/Vol III/1998. Jakarta: P3M

3) Berusaha memahami kehadiran bank-BPR, dalam majalah AULA. Maret 1991.

4) Dengan Fikih Semua Bisa Halal. Surabaya: Jurnal Gerbang. Vol 05. No 02 Oktober-Desember 1999.

5) Disini hebatnya NU, dalam majalah AULA NU. No. 04 tahun XXXIII April 2011

${ }^{1}$ Abdul Muchith Muzadi, NU Dalam Perspektif Sejarah Dan Ajaran, refleksi 65 tahun ikut NU, Surabaya: Khalista, 2006, hlm: 172-173.

128 | FENOMENA, Vol.19 No. 2 Oktober 2020 
6) Pedoman bagi kaum muslimin Indonesia dalam hidup bermasyarakat berbangsa dan bernegara. Jember: BP7, 1994

7) Fikih perempuan praktis. Surabaya: khalista, 2006.

8) Melihat bank dengan teropong berlensa rangkap ahklaq dan fikih. Dalam majalah AULA NU. Februari 1991.

9) Mengenal nahdlatul ulama, jember: masjid sunan kalijaga. 2006.

10) NU dalam prspektif sejarah dan ajaran. Surabaya: khalista 2006.

11) NU dan fikih kontekstual, Yogyakarta: LKPSM, 1995.

12) Rumah tangga markas kehidupan. Tulisan tidak dipublikasikan.

13) Semua elit politik perlu psikiater. Dalam majalah aula NU edisi mei 2001

14) System bermazhab paling proporsional realistic. Makalah tidak diterbitkan.

15) 'Tulisan sekitar 37 topik di Bulletin Masjid Jami’ Al-Baitul Amien Jember. ${ }^{1}$

16) Dan lain sebagainya.

\section{d. Pendidikan ahlak dalam pandangan KH. Abdul Muchith Mu- zadi}

\section{Pola Hidup Birrul Walidain}

Di bawah ini adalah beberapa konsep pemikiran KH. Abdul Muchith Muzadi tentang etika kepada kedua orang tua;

Artinya :"Sembahlah Allah dan janganlah kamu mempersekutukan-Nya dengan sesuatupun. dan berbuat baiklab kepada dua orang ibu-bapa" (An-Nisa: 36). Birrul Walidain, artinya bersikap baik terhadap dua orang tua (ayah dan ibu). Sikap baik yang dibuktitan dengan tingkah laku perbuatan yang baik.

Islam menempatkan birrul walidain ini sebagai kewajiban dengan urutan nomor dua sesudah beribadah kepada Allah dan sebaliknya menempatkan Uququl Walidain sebagai larangan dengan urutan nomor dua sesudah syirik (menyekutukan Allah). Alangkah panting dan gawatnya urusan orang tua di dalam ajaran Islam. Rasulullah SAW bersabda :

"Apakah aku (perlu) memberitabukanmu kalian tentang sebesar-besar dosa besar?”. Diulang tiga kali, maka kami menjawab "Benar, Ya Rasulullah!”,

\footnotetext{
1 Data dari tahun 1990-an. 6
} 
Beliau bersabda "Menyekutukan Allah (syirik), bersikap tidak baik terhadap kedua orang tua (uququl walidain = menyakitkan hati orang tua)".

Ketika itu beliau berangkat lalu duduk dan bersabda (lagi): "(Juga) berkata palsu dan memberikan kesaksian palsu". Beliau terus mengulangulangnya sehingga kami berkata: "Semoga beliau berhenti bersabda". Riwayat Bukhari dan Muslim. dari Shahabat Abu Bakar.

Kata KH. Abdul Muchith Muzadi menguraikan lebih lanjut dalam konteks uraian di atas;

Pada umumnya, birrul walidain hanya kita anggap sebagai kewajiban keagamaan, kewajiban ukhrowi yang akan mendapat balasan pahala besar bagi para pelakunya dan akan mendapat siksa bagi yang bersikap sebaliknya (uququl walidain).

Pandangan di atas tersebut, merupakan pandangan normative yang diajarkan di dunia pendidikan pesantren. Bahkan pemahaman demikian, menjadi semacam doktrin, dimana para anak harus menunjukkan ketaatannya kepada kedua orang tua secara totalitas, bahkan walau beda agama sekalipun.

Pandangan yang demikiam ini, sepenuhnya adalah benar. Pemeluk Islam seharusnya pertama kali menilai segala sesuatu dari sudut ukhrowinya. Melakukan shalat umpamanya, pertama kali harus kita pandang sebagai kewajiban yang ditetapkan oleh Allah dengan sanksi ukhrowi, tidak harus dipertimbangkan dahulu untung rugi duniawi bagi pelakunya. Membayar zakat umpamanya, pertama kali harus kita pandang sebagai kewajiban ukhrowi sebelum kita memikirkan manfaatnya bagi kepentingan duniawi.

Uraian KH. Abdul Muchith Muzadi sebenarnya sangat sederhana bahkan dengan sangat mudah kita memahaminya. Namun demikian, banyak orang justru terkadang abai bahkan cuek dengan ajaran Islam yang sangat mulia ini. Oleh karenanya, dengan menghadirkan pemikiran KH. Abdul Muchith Muzadi diharapkan kita dapat mencerna ajaran Islam secara lebih mendalam lagi.

Namun, juga sama sekali tidak salah, kalau kita memikirkan manfaat dari segala macam kewajiban yang ditetapkan oleh Allah SWT. bukan karena meragukannya, melainkan justru karena didorong oleh keyakinan bahwa segala yang diwajibkan oleh Allah SWT. Tentu besar manfaatnya bagi yang

130 | FENOMENA, Vol.19 No. 2Oktober 2020 
bersedia melakukannya. Bukan saja manfaat ukhrowi, manfaat bagi kehidupan kita di dunia ini.

Banyak perintah di dalam Al Qur'an dan Al Hadits, supaya kita beriman, taat dan berpikir. Beriman artinya memiliki keyakinan mutlak, teguh dan benar. Taat artiaya patuh melaksanakan perintah berdasar iman. Berpikir artinya mengembangkaa pikiran supaya dapat melaksankan kepaTuban dengan lebih mantap dan sempurna.

Kerangka fikir KH. Abdul Muchith Muzadi sebenarnya bukanlah kerangka doctrinal sebagaimana diajarkan oleh banyak orang. Namun kerangka fikir KH. Abdul Muchith Muzadi lebih pada kerangka fikir menguraikan secara rasional, logis dan mudah dicerna. Sehingga keberadaan perintah Al-Qur'an merupakan suatu fakta yang dapat dipaparkan secara lugas dan mudah dipahami. Berikut KH. Abdul Muchith Muzadi lebih lanjut menguraikannya kepada kita semua;

Pada dasarnya setiap orang normal memiliki kecenderungan untuk bersikap baik terhadap orang tuanya (birrul walidain). Naluri dan akal sebat manusia selalu mengarah demikian, sama dengan adanya kecenderungan pada setiap orang mencintai anaknya, berani bersusah payah dan berkorban untuk kepentingan anaknya.

Dua macam kecenderungan timbal batik ini merupakan tanda bukti kemahabijaksanaan dan kemahabesaran Allah SWT. Bayangkan, seandainya tidak ada lagi manusia yang cinta anak dan tidak ada lagi anak yang bersikap baik terhadap orang tuanya.

Kalau dalam suatu masyarakat yang besar tidak mengasihi yang kecil dan yang kecil tidak menghormati yang besar, maka apalah jadinya. Apalagi, kalau yang besar itu orang tuanya dan yang kecil itu anaknya. Rasulullah SAW. bersabda

"Tidak tetmasuk golonganku (yang baik), orang yang tidak mengasibi yang kecil dan tidak menghormati yang besar".

Berikut lanjutan pemikiran KH. Abdul Muchith Muzadi "Kasih sayang orang tua (ayah ibu) kepada anak dan sebaliknya hormat anak kepada ayah ibunya adalah dua tali pengikat bagi manusia untuk tetap martabat kemanusiaannya. Kewajiban kita dalam memelihara dan mengembangkan rahmat dan karunia Al-lah SW'T ini dengan penuh kesungguhan dan keseksamaan. Bersyukurlah kita, dengan memanfaatkan rahmat menurut ajaran Allah pemberi rahmat".

FENOMENA, Vol.19No. 2Oktober 2020 | 131 
Lebih lanjut pemikiran KH. Abdul Muchith Muzadi sebagai tergambarkan dalam uraian berikut ini; "Pertumbuhan dan perkembangan bibit kecenderungan tersebut tidak selalu sesuai dengan keinginan kita. Adakalanya terganggu, terhambat, terhalang atau menyimpang. Gejala terganggunya birrul walidain tampak pada anak, tetapi tidak selalu penyebab utamanya tedetak pada anak saja. Mungkin saja orang tua ikut bersalah, mungkin juga masyarakat dan lingkungan sekitar itu menjadi penyebab anak tidak bersikap baik terhadah orang tuanya".

Konsep etika, tidak serta merta lahir dan berkembang dengan sendirinya, namun hal itu memerlukan pembinaan, perawatan dan latihan dari lingkungan keluarga, berikut pemikiran KH. Abdul Muchith Muzadi; "memang, bibit birrul walidain yang sudah ada pada setiap anak itu, memerlukan perawatann, pemeliharaan, pemupukan, supaya tumbuh dengan baik. Orang tua dan para pendidiklah yang terutama berke-wajibau mengembangkan birrul walidain ini dengan menjaga supaya tidak terganggu. Usaha mengembangkan birrul walidain ini tidak cukup hanya dengan komando saja, tidak cukup hanya dengan pidato saja, tidak cukup hanya dengan membentak saja".

Selain itu, berikut gagasan yang cukup unik dari KH. Abdul Muchith Muzadi tentang birrul wa lidain;

Gangguan terhadap pertumbuhan birrul walidain ini, mungkin saja terdapat pada anak terlalu bandel, mungkin terdapat pada orang tua yang salah langkah atau tidak jarang timbul karena pengaruh lingkungan yang kurang menguntungkan tumbuhnya birrul walidain. Bahkan mungkin karena situasi pendidikan yang terlalu intele-ktualistis dan tidak berorientasi kepada kehidupan keluarga. Gaya hidup yang serba sibuk sekarang ini yang juga menyebabkan sangat sibuknya para pendidik, ternyata menyebabkan kelonggaran keakraban batin antara orang tua dan anak, kemesraan hubungan antara keduanya. Akhirnya, hal ini menyebabkan menurunnya birrul walidain.

Gagasan KH. Abdul Muchith Muzadi di atas, sangat kontekstual dengan kehidupan masyarakat modern saat ini, namun demikian bukan hanya itu, berikut juga gagasan cemerlang dari KH. Abdul Muchith Muzadi tentang konsep etika birrul walidain; "masalah lain yang patut menjadi perhatian ialah adanya semacam ‘krisis ketaula-danan’ bagi anak-anak dan

132 | FENOMENA, Vol.19 No.2Oktober 2020 
para remaja kita. Para remaja selalu mencari tokoh pujaan yang dapat menjadi "tokoh tauladan bagi mereka. Yang paling ideal ialah kalau orang tuanya sendiri (ayah ibu) dapat dijadikarr tokoh tauladan itu, disampiug gurugurunya dan beberapa pemimpinnya (pemimpin organisasi, pemimpin masyarakat atau pemimpin negara). Untuk dapat menjadi "tokoh" bagi remaja, haruslah memiliki sesuatu yang pantas "dikagumi" dan memiliki "pengertian" terhadap aspirasi remaja".

Kompleksitas pemikiran brilian KH. Abdul Muchith Muzadi sebenarnya dapat kita rasakan jika dibandingkan dengan pemikiranpemikiran para tokoh yang tidak dilahirkan di Indonesia. Sebagai tokoh, ulama', kiai, intelektual dan ilmuan yang lahir dan dibesarkan di Indonesia, tentu hal ini memberikan semacam cara pandang yang kontekstual terhadap realitas kemasyarakatan yang sedang terjadi hari ini. Seperti pandangannya berikut ini;

Kalau orang tuanya, guru-gurunya dan pemimpin-pemimpinnya dianggap tidak memenuhi syarat untuk dijadikan tokoh tauladan, maka para remaja akan mencari pada orang-orang lain. Tidak mustahil mereka menokohkan John Travolta, John Lenar atau John-John yang lain. Inilah gejala krisis ketauladanan bagi para remaja "Krisis ketauladanan” inilah yang merupakan salah satu penyakit pada jaman ini yang insya Allah akan dapat dicegah atau diobati dengan "Pola Hidup Birrul Walidain"

"Pola Hidup birrul walidain" berlandasan atas kesadaran yang mendasar bahwa "Ayah den lbu" adalah yang paling berhak dan berkewajiban bagi anak. Guru, pendidik dan pemimpin adalah pembantu bagi ayah dan ibu untuk pendidikan dan pembinaan anak. Mereka berkewajiban menegakkan kewibawaan ayah dan ibu di mata anak-anakaya. Sama sekali tidak boleh ada yang bersikap dan berbuat yang sebaliknya, merendahkan martabat ayah dan ibu di mata anaknya.

Gaya hidup di zaman "modern” sekarang ini, banyak hal yang disengaja atau tidak, disadari atau tidak, telah menyebabkan longgarnya hubungan anak dengan ayah ibunya, menyebabkan berkurangnya kewibawaan ayah ibu terhadap anak-a-anaknya. Setelah terjadi hal-hal yang "gawat" (perkelahian massal antar kelompok anak-anak), baru orang ramairamai "menghimbau" orang tua anak-anak supaya "memperhatikan" pendidikan anak-a-anaknya. Orang-orang tuapun baru "terkejut" karena anaknya yang disekolahkan di lembaga Pendidikan favorit dengan gedungnya 
yang mewah, dengan guru-gurunya yang berijazah resmi itu masih harus ikut "mengawasi" dan "mengendalikan" anak-anakaya, justru pada jam-jam si anak barada di sekolah.

Rupanya tanpa disadari, titik pusat pembinaan anak-anak pada zaman ini, secara diam-diam sudah dipindah dari rumah tangga, keluarga, ayah ibunya ke "sekolah". Disadari atau tidak, hal ini telah menyebabkan menurunnya kewibawaan orang tua, kewibawaan keluarga terhadap anak, padahal kewibawaan sekolah tidak pernah stabil, karena tidak memiliki syarat untuk menjadi stabil dan memang tidak pernah diimpikan bahwa sekolah akan menggantikan fungsi ayah ibu di dalam pendidikan dan pembinaan anak-anak. Hanya "kelalaian" saja menyebabkan kita terperosok kepada sikap intelektualistis, sehingga memandang orang tua anak, keluarga anak yang tampak "tidak intelektual", tidak mendapat perhatian sewajarnya.

Kiranya sudah waktunya kita bersama-sama merenungkan kembali tanggung jawab kita bersama mendidik dan membina anak-anak kita. Bagaimana memulihkan kembali kewibawaan ayah ibu terhadap anakanaknya, memulihkan kembali “birrul walidain” pada jiwa anak-anak kita.

Cara pandang KH. Abdul Muchith Muzadi di atas, merupakan cara pandang yang sangat sederhana, kontekstual, mendalam dan sekaligus dapat dijadikan sebagai alat pembaca terhadap realitas masyarakat Indonesia yang mengalami "kekalutan" dalam bidang pendidikan nasional.

\section{KESIMPULAN}

Terkait dengan kesimpulan penelitian ini, dapat diuraiakan sebagai berikut; Pertama, latar belang kehidupan, pendidikan dan pengabdian di dalam NU. KH. Abdul Muchith Muzadi dilahirkan di Bangilan Tuban, pada tanggal 19 jumadil awwal 1344 H/ 4 Desember 1925 M. beliau merupakan kader sekaligus aktivis NU yang dari sejak awal berjuang bersama putra KH. Hasyim Asy'ari, yakni KH. Wahid Hasyim. Dan untuk menerapkan pengetahuannya itu, maka setamat dari Tebuireng ia kembali ke kampung halamannya di Tuban dengan mendirikan Madrasah Salafiyah.

Keaktifan Abdul Muchith di dunia pergerakan dan pendidikan, ia jalani sepulang dari pondok asuhan KH. Hasyim Asy'ari ini. Saat Jepang datang menjajah Indonesia, bersama teman-temannya dia mendirikan koperasi desa dengan nama Tokoku ( $\mathrm{Ku}$ dalam Bahasa Jepang artinya desa), sekaligus menjadi sekretarisnya selama dua tahun, 1942-1944. Barangkali karena mem-

134 | FENOMENA, Vol.19 No. 2 Oktober 2020 


\section{Ahmad Mutohar, Zainal Anshari}

iliki aliran darah pedagang, menjadikan Abdul Muchith betah beraktivitas di dalamnya.

Abdul Muchith juga langsung bergabung dengan Hizbullah ketika laskar itu mendirikan cabangnya di daerah Bangilan. Sayang dia tidak bisa mengikuti latihan perwira Hizbullah angkatan pertama di Cibarusa, karena tidak diizinkan orang tuanya. Ia bergabung dengan Hizbullah ketika para alumni pendidikan angkatan pertama itu membentuk Hizbullah di daerah masing-masing.

Ketika suasana kembali normal, pada tahun 1952 mbah Muchit mendirikan Sekolah Menengah Islam (SMI), selanjutnya pada tahun 1954 juga mendirikan Madrasah Muallimin Nahdlatul Ulama. Begitu juga ketika pada tahun 1961 mendapatkan tugas sebagai pegawai di IAIN Sunan Kalijogo Yogyakarta, maka digunakan kesempatan untuk belajar lagi dengan mengikuti kuliyah di Universitas Cokroaminoto. Di kota gudeg itulah rupanya ia menemukan ide-ide pembaharuan. Maka ketika ditugaskan di IAIN Malang tahun 1963 iapun sempat merintis SMP NU. Begitu juga ketika menjadi PD II di IAIN Sunan Ampel Jember ia juga mendirikan Madrasah Tsanawiyah. Di seluruh sekolahan yang dirintisnya itu ia bertindak sebagai kepala sekolah.

Kedua, beberapa karya tulis ilmiah KH. Abdul Muchith Muzadi. Sebagai berikut; 1) Beberapa Masalah Kewanitaan Dan Kepemimpinan Di Kalangan Wanita, 1974, makalah tidak diterbitkan. 2) Bermazhab. Sosiologis Atau Takut Resiko? Dalam pesantren No 4/Vol III/1998. Jakarta: P3M. 3) Berusaha memahami kehadiran bank-BPR, dalam majalah AULA. Maret 1991. 4) Dengan Fikih Semua Bisa Halal. Surabaya: Jurnal Gerbang. Vol 05. No 02 Oktober-Desember 1999. 5) Disini hebatnya NU, dalam majalah AULA NU. No. 04 tahun XXXIII April 2011. 6) Pedoman bagi kaum muslimin Indonesia dalam hidup bermasyarakat berbangsa dan bernegara. Jember: BP7, 1994. 7) Fikih perempuan praktis. Surabaya: khalista, 2006. 8) Melihat bank dengan teropong berlensa rangkap ahklaq dan fikih. Dalam majalah AULA NU. Februari 1991, dan lain sebagainya.

Ketiga, Konsep pendidikan ahlak dalam pandangan KH. Abdul Muchith Muzadi. Pertama, konsep pola hidup birrul walidain. Menurut KH. Abdul Muchith Muzadi, Islam menempatkan birrul walidain ini sebagai kewajiban dengan urutan nomor dua sesudah beribadah kepada Allah dan sebaliknya menempatkan Uququl Walidain sebagai larangan dengan urutan 
nomor dua sesudah syirik (menyekutukan Allah). Kedua, wajib bela negara menurut Islam, KH. Abdul Muchith Muzadi dalam konteks ini berpendapat bahwa, kaum pesantren tidak mengikuti pendapat yang mewajibkan seluruh kaum muslimin sedunia berada di bawah satu kekuasaan politik, yang diwajibkan adalah ukhuwah di antara mereka, baik secara individual, kelompok maupun pemerintah/ kenegaraan dalam wujud kerjasama, saling membantu dan saling menghargai satu sama lain.

\section{DAFTAR PUSTAKA}

Abbas, Sirajuddin, I'tiqad Ablussunnah Wal Jamaah, Jakarta: Pustaka Tarbiyah Baru, 2008.

Abdusshomad, Muhyiddin, Aqidah Ablussunnah Wal Jamaab; Terjemah dan Syarh Aqidab Al Awam, Surabaya: Khalista dan LTN NU Jember, 2009.

Asrori, A Ma'ruf, Etika Belajar Bagi Penuntut Ilmu; Terjemah Taklimul Mutaallim, Surabaya: Al-Miftah, 2012.

Dhofier, Zamakhsyari, Tradisi Pesantren; Memadu Modernitas Untuk Kemajuan Bangsa, Yogyakarta: Pesantren Nawesea Press, 2009.

Dhofier, Zamakhsyari, Tradisi Pesantren; Studi Pandangan Hidup Kiai dan Visinya Mengenai Masa Depan Indonesia, Jakarta: LP3ES, 2011.

Dhofier, Zamakhsyari, Tradisi Pesantren; Studi Tentang Pandangan Hidup Kiai, Jakarta: LP3ES, 1994.

Harisudin, Mohammad Noor, Peran Domestik Perempuan Menurut KH. Abd. Muchith Muzadi. Surabaya: IAIN Sunan Ampel, 2012. Disertasi program doktor.

Muchtar, Masyhudi dkk, Aswaja An-Nahdliyah, Ajaran Ablussunnah Wal Jamaah Yang Berlaku Dilingkungan Nabdlatul Ulama', Surabaya: Khalista \& LTN NU Jawa Timur.

Muzadi, Abdul Muchith, Dengan Fikih Semua Bisa Halal, Surabaya: Jurnal Gerbang, 1999. No 2, Vol 5 (Oktober-Desember).

Muzadi, Abdul Muchith, Fikih Perempuan Praktis, Surabaya: Khalista.

Muzadi, Abdul Muchith, Manivestasi Keluarga Sakinah dalam Pendidikan Anak, Jember: Jurnal Al Adalah, 1998. Vol. 1, No 2 (Agustus).

Muzadi, Abdul Muchith, Menata NU dengan Lisan dan Teladan, Surabaya: Jurnal Gerbang, 2002. No 12, Vol V (Juli-September).

136 | FENOMENA, Vol.19 No. 2Oktober 2020 
Muzadi, Abdul Muchith, Mengenal Nabdlatul Ulama, Jember: Masjid Sunan Kalijaga, 2004.

Muzadi, Abdul Muchith, NU dalam Perspektif Sejarah \& Ajaran Refleksi 65 Tabun Ikut NU), Surabaya: Khalista, 2006.

Muzadi, Abdul Muchith, NU Dalam Perspektif Sejarah Dan Ajaran, refleksi 65 tahun ikut NU, Surabaya: Khalista, 2006.

Muzadi, Abdul Muchith, NU dan Fikih Kontekstual, Yogyakarta: LKPSM NU DIY, 1995.

Nata, Abudin, Pemikiran Para Tokoh Pendidikan Islam; Seri Kajian Filsafat Pendidikan Islam, Jakarta: Rajawali Press, 2000.

Putra, Andiono, "Formulasi Nalar Fiqh KH. Abdul Muchith Muzadi", Jember; STAIN Jember, 2005. Skripsi tidak diterbitkan.

Rofik, Ainur, Pembaruan Pesantren, Respons Terbadap Tuntutan Transformasi Global, Jember: STAIN Jember press, 2012.

Siddiq, Achmad, Khittah Nabdliyah, Surabaya: Khalista \& LTN NU Jawa Timur, 2005.

Soebahar, Abd. Halim, Modernisasi Pesantren; Studi Transformasi Kepemimpinan Kiai Dan System Pendidikan Pesantren, Yogyakarta: LKIS, 2013.

Sukardi, Metodologi Penelitian Pendidikan; Kompetensi Dan Prakteknya, (Jakarta: Bumi Aksara, 2008.

Sutarto, Ayu, Menjadi NU Menjadi Indonesia. Surabaya: Khalista \& Kopyawisda Jatim, 2008.

Wahid, Abdurrahman, Kiai Nyentrik Membela Pemerintah. Yogyakarta: LKIS, 2010.

Wahid, Abdurrahman, Menggerakkan Tradisi, Esai-Esai Pesantren, Yogyakarta: LKIS, 2010.

\section{Data Internet}

http://nu1926.blogspot.com/2010/09/mbah-muchith-berbincang-nu-dannegara.html, diunduh pada senin, 29 September 2014.

http://perpus.stainsalatiga.ac.id/seg.php?a=detil\&id=1600, diakses pada 5/9/2014.

http://ruangbening.wordpress.com/2010/01/17/kh-abdul-muchithmuzadi, diakses pada, Senin, 6/10/2014.

http://suara-santri.tripod.com/files/profil/profil4.htm, diunduh pada $13 / 10 / 2014$. 
Pendidikan Ahlak Dalam Pandangan KH. Abdul Muchith Muzadi

http://suharpaistaid.files.wordpress.com/2012/03/konsep-pendidikanakhlak-ibnu-miskawaih.pdf, diakses pada 9/10/2014.

http://wija091.blogspot.com/2008 0107 archive.html, diakses pada 2/10/2014.

http:/ /www.nu.or.id/page.php?lang=id\&menu=news_view\&news_id=1187 3

138 | FENOMENA, Vol.19 No. 2 Oktober 2020 